Original Article

Received December 2021 / Revised February 2022 / Accepted February 2022

Spizaetus: Jurnal Biologi dan Pendidikan Biologi

p-ISSN: 2716-151X e-ISSN: 2722-869X

\title{
GAMBARAN SIKAP PEDULI LINGKUNGAN SERTA PERILAKU HIDUP BERSIH DAN SEHAT (PHBS) DI SMA BUDI MULIA KOTA BOGOR PADA MASA PANDEMI COVID-19
}

\author{
Kenia $^{1^{*}}$, Sunarto ${ }^{2}$, Fajar Adinugraha ${ }^{3}$ \\ 1,2,3 Pendidikan Biologi, Universitas Kristen Indonesia, Jakarta Timur, Indonesia \\ *Email: keniapujianto84@gmail.com
}

\begin{abstract}
Abstrak. Pandemi Covid-19 mengharuskan setiap orang untuk melakukan Perilaku Hidup Bersih dan Sehat (PHBS). Selain itu, setiap orang juga perlu memiliki kepedulian terhadap lingkungan. SMA berbasis Katolik memiliki karakter yang cukup kuat mengenai kepedulian lingkungan terlebih terdapat juga katekese ekologi. Penelitian ini bertujuan untuk mengetahui gambaran sikap peduli lingkungan serta Perilaku Hidup Bersih dan Sehat (PHBS) di SMA Budi Mulia Kota Bogor pada masa pandemi Covid-19. Metode penelitian yang digunakan antara lain: survei, observasi, dan wawancara. Populasi penelitian ini adalah warga SMA Budi Mulia Bogor (kepala sekolah, guru, karyawan, dan siswa) dengan jumlah sampel responden sebanyak 255 orang. Hasil dari penelitian menunjukkan bahwa warga SMA Budi Mulia Kota Bogor sudah memiliki sikap peduli lingkungan sebesar $86.06 \%$ dari indikator yang diharapkan, seperi: (1) penggunaan energi; (2) pemanfaatan air; (3) pengelolaan sampah; (4) pengetahuan terhadap pencemaran; (5) penggunaan plastik; (6) penggunaan transportasi umum; dan (7) perawatan dan pemanfaatan lingkungan sekitar. Perilaku Hidup Bersih dan Sehat warga SMA Budi Mulia Kota Bogor sebesar 88.13 \% dari indikator yang diharapkan, seperti: (1) penggunaan air bersih; (2) mencuci tangan dengan baik dan benar; (3) mengkonsumsi makanan sehat dan bergizi; (4) melakukan aktivitas fisik setiap hari; (5) menuruti protokol kesehatan pemerintah; dan (6) istirahat yang baik dan cukup. SMA Katolik sebaiknya menjadi teladan dalam gerakan sikap peduli lingkungan dan PHBS karena didukung dan sesuai semangat Gereja Katolik dalam kaitannya dengan lingkungan.
\end{abstract}

Kata Kunci: sikap peduli lingkungan, PHBS, SMA Budi Mulia Bogor, Pandemi Covid,

DOI: http://dx.doi.org/10.55241/spibio.v3i1.51 


\section{Pendahuluan}

Pada tahun 2017, Indonesia memperoleh IPKLH (Indeks Perilaku Ketidakpedulian Lingkungan Hidup di Indonesia) sebesar 0.51 (nilai tertinggi 1.00), dengan indeks ketidakpedulian tertinggi yaitu terhadap pengelolaan sampah dengan nilai 0.72 (nilai tertinggi 1.00) (Subdirektorat Statistik Lingkungan Hidup, 2018). Pada tahun 2019, Indonesia menjadi negara sebagai penghasil sampah terbesar di dunia setelah China (Gromico, 2019). Banyaknya sampah mengakibatkan terjadinya permasalahan sampah.

Permasalahan sampah yang terjadi di kawasan perkotaan disebabkan oleh beberapa faktor antara lain: pertumbuhan penduduk, pertumbuhan ekonomi, pola konsumsi, perilaku penduduk, kepadatan penduduk dan bangunan (Lathif, 2019). Menurut data IPKLH, provinsi Jawa Barat memiliki IPKLH tertinggi di Pulau Jawa-Bali dengan indeks sebesar 0.54 dengan dimensi tertinggi yaitu pengelolaan sampah sebesar 0.72 (Subdirektorat Statistik Lingkungan Hidup, 2018). Kota Bogor merupakan salah satu kota di Jawa Barat yang memiliki tingkat populasi dan aktivitas masyarakat yang cukup tinggi. Disamping itu, Kota Bogor juga sering dijadikan lokasi wisata bagi warga luar kota seperti Bandung dan Jakarta. Dengan tingginya populasi dan aktivitas masyarakat serta menjadi kota wisata, Kota Bogor tidak luput dari permasalahan sampah dan lingkungan.

Masa pandemi Covid-19 yang sedang melanda menjadikan kebersihan lingkungan menjadi sangat penting guna mencegah penularan penyakit tersebut maupun penyakit lainnya. Dengan maraknya Covid-19 yang beredar di Indonesia, pemerintah memberikan kebijakan pencegahan penularan Covid-19 yaitu 3M (memakai masker, mencuci tangan, dan menjaga jarak). Perilaku Hidup Bersih dan Sehat (PHBS) memiliki kaitan yang erat dengan pencegahan penyebaran Covid-19 (Antari et al., 2020). Sikap peduli lingkungan memiliki pengaruh terhadap PHBS karena kedua hal ini memiliki pengaruh terhadap kesehatan, kebersihan dan keamanan di lingkungan sekitar (Sari \& Ria, 2018).

Nurwanti (2011) menyatakan bahwa peduli lingkungan merupakan sikap serta tindakan untuk mencegah kerusakan pada lingkungan di sekitarnya, serta upaya uttuk memperbaiki kerusakan yang sudah terjadi (Handayani, 2013). Penanaman karakter peduli lingkungan hidup sejak dini dapat melalui pendidikan lingkungan hidup (PLH) dan pelaksanaan program adiwiyata di sekolah (Gunawan \& Guslinda, 2019).

Penanaman pendidikan karakter dan peduli lingkungan dapat dilihat salah satunya pada sekolah berbasis Katolik. Hal ini karena sekolah katolik beracuan kepada ajaran Gereja beserta katekase ekologi. Agar dapat mengurangi dan mencegah permasalahan lingkungan, perlu adanya sikap peduli lingkungan serta perilaku hidup bersih dan sehat. SMA Budi Mulia Kota Bogor merupakan sekolah berbasis Katolik.

Sebagian besar Sekolah Katolik dikenal memiliki citra yang baik bahkan menjadi role model dalam pendidikan karakternya. Pelaksana dunia Pendidikan Katolik dan Insan Pendidikan Katolik harus memahami, menghayati dan mengamalkan peranan hirarkis dalam karya kerasulan pendidikan seperti Dokumen Gravissimum Educationis (GE). Sekolah katolik dibimbing oleh Kuasa gerejani yang berwenang sehingga sekolah mengikuti proses pembentukan diri, akhlak, tabiat dan kepribadian seutuhnya agar kelak 
menjadi manusia yang utuh (Wetu, 2017). Dalam permasalahan lingkungan, Gereja Katolik juga memiliki katekase ekologi. Katekase ekologi merupakan kegiatan pembinaan iman atau pengajaran yang dilakukan seluruh umat untuk menyadari dan menanggapi kehadiran Kristus dan berkarya di dalam alam ciptaan dan didalam lingkungan hidup

\section{Metode}

Tempat penelitian adalah SMA Budi Mulia Kota Bogor pada bulan Januari-Mei 2021. Faktor yang diteliti adalah Sikap Peduli Lingkungan dan Perilaku Hidup Bersih dan Sehat (PHBS). Metode Penelitian adalah survei, observasi, dan wawancara. Populasi dalam penelitian ini adalah SMA Budi Mulia Bogor, sebanyak 705 orang yang terdiri atas 1 (satu) kepala sekolah, 32 guru, 10 karyawan, dan 662 siswa yang terdiri atas 3 (tiga) angkatan yaitu kelas X, XI, dan XII.

Teknik pengambilan sampel yaitu probability sampling-proportionate stratified random sampling. Probability sampling merupakan teknik pengambilan sampel dengan memberikan peluang yang sama bagi setiap anggota populasi untuk menjadi sampel, sedangkan proportionate stratified random sampling merupakan teknik yang digunakan untuk menentukan jumlah sampel di dalam populasi yang berstrata dan proposional (Sugiyono, 2016). Jumlah

\section{Hasil dan Pembahasan}

Bagian ini terdiri atas 2 (dua) sub topik yaitu, 1) gambaran sikap peduli lingkungan SMA Budi Mulia Kota Bogor, dan 2) gambaran sikap Perilaku Hidup Bersih dan Sehat. Selanjutnya, juga dibahas terintegrasi dengan data observasi serta wawancara. SMA Budi Mulia merupakan sekolah yang bernaungan manusia (Listyanto, 2019). Berdasarkan hal-hal tersebut, tujuan dalam penelitian ini, yaitu untuk mengetahui gambaran sikap peduli lingkungan dan Perilaku Hidup Bersih dan Sehat (PHBS) di SMA Budi Mulia Kota Bogor pada masa pandemi Covid-19. sampel dihitung menggunakan rumus Taro Yamane, dihasilkan sampel sebanyak 255 responden, yaitu 1 kepala sekolah, 12 guru, 4 karyawan, 38 siswa $X$ IPA, 36 siswa X IPS, 36 siswa XI IPA, 42 siswa XI IPS, 45 siswa XII IPA, dan 42 siswa XII IPS.

Teknik pengambilan data Sikap Peduli Lingkungan dan PHBS menggunakan kuesioner online yang sudah dinyatakan valid oleh validator. Jumlah pernyataan adalah 40 butir pernyataan. Observasi digunakan untuk melihat kondisi lingkungan SMA dan wawancara digunakan untuk mempertegas jawaban dari kuesioner. Teknik analisis data menggunakan statistika deskriptif. Statistika deskriptif dengan mencari rerata skor kemudian dibuat dalam garis kontinum dengan rumus sebagai berikut.

Tingkat persetujuan $=$ (Jumlah skor yang diperoleh dari penelitian: Jumlah skor ideal (kriterium) untuk seluruh item) $x 100 \%$

di bawah komunitas bruder-bruder Budi Mulia dalam Yayasan Budi Mulia. SMA Budi Mulia memiliki fasilitas yang lengkap dengan keunikan terdapat area yang disebut "pintu surga". Area ini dimanfaatkan untuk hidroponik.

\section{Sikap Peduli Lingkungan}

$$
\text { Sikap peduli lingkungan }
$$
merupakan sebuah respon manusia 
untuk lebih memperhatikan dan mengindahkan keadaan sekitarnya demi keberlangsungan kehidupan manusia dan makhluk hidup lainnya. Tindakan memperhatikan dan mengindahkan keadaan dapat dilakukan dengan cara menjaga, merawat dan melestarikan lingkungan yang ada, mencegah lingkungan dari kerusakan, serta memperbaiki lingkungan yang sudah rusak. Indikator Sikap Peduli Lingkungan dalam penelitian ini antara lain: (1) Penggunaan energi; (2) pemanfaatan air; (3) pengelolaan sampah; (4) pengetahuan terhadap pencemaran; (5) penggunaan plastik; penggunaan transportasi umum; dan (7) perawatan dan pemanfaatan lingkungan di sekitar.

Data sikap peduli lingkungan per strata disajikan pada Gambar 1. Apabila dilihat per strata, maka kesimpulan tingkat persetujuan terhadap sikap peduli lingkungan adalah sebagai berikut.
a. Kepala Sekolah $=(108: 120)$ $x 100 \%=90 \%$ dari yang diharapkan $100 \%$
b. Guru $=(103.31: 120) \quad \times 100 \%=$ $86.09 \%$ dari yang diharapkan $100 \%$
c. Karyawan = (102.5:120) $x 100 \%=85.42 \%$ dari yang diharapkan $100 \%$
d. Siswa $=(99.3: 120) \times 100 \%$ $=82.75 \%$ dari yang diharapkan $100 \%$

Rerata skor yang diperoleh dari 255 responden yang terdiri atas kepala sekolah, guru, karyawan, dan siswa adalah 103.277. Dengan demikian, sikap peduli lingkungan warga SMA Budi Mulia Kota Bogor = $(103.28: 120) \times 100 \%=86.06 \%$ dari yang diharapkan $100 \%$..
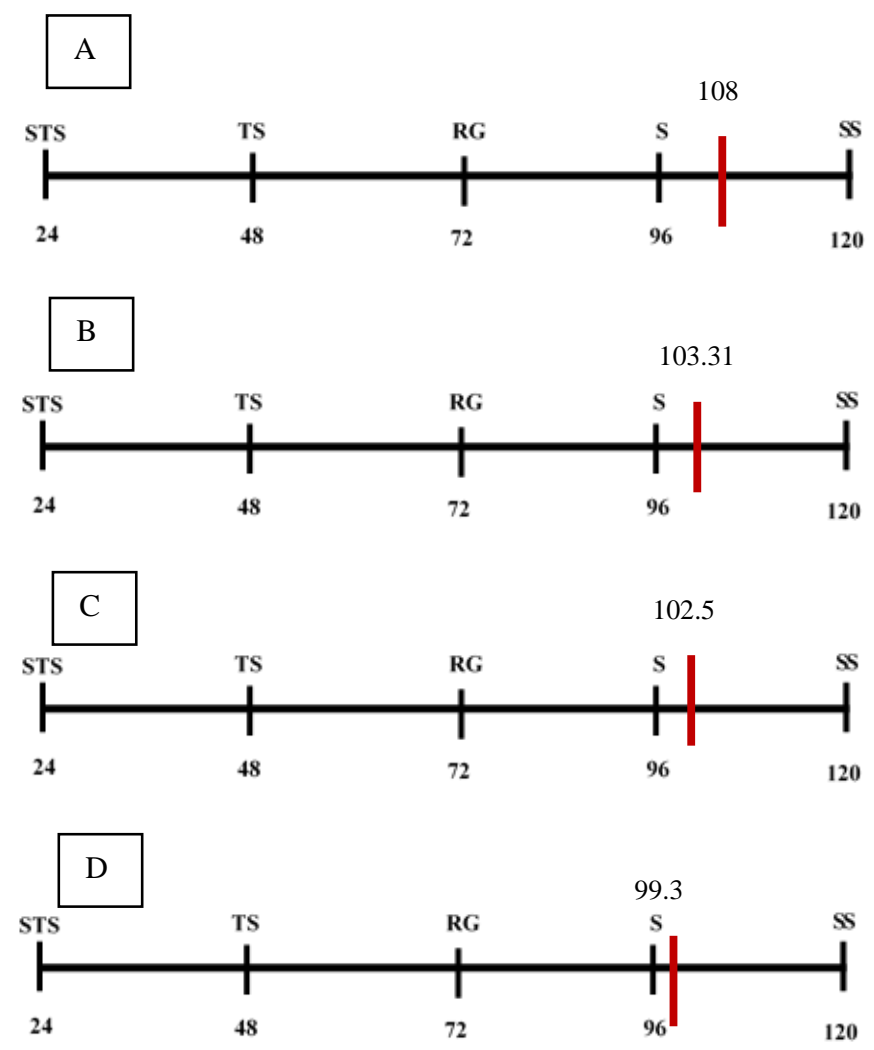
Gambar 1. Garis Kontinum Sikap Peduli Lingkungan (A) Skor Kepala Sekolah; (B) Skor Guru; (C) Skor Karyawan; (D) Skor Siswa (Sumber: Dokumen Penulis)

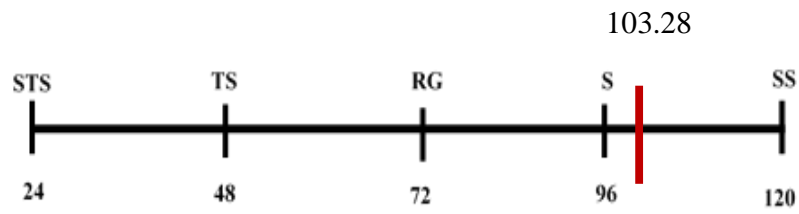

Gambar 2. Garis Kontinum Sikap Peduli Lingkungan warga SMA Budi Mulia Kota Bogor

Sumber: Dokumen Penulis

Berdasarkan hasil observasi
mengenai kondisi lingkungan,
lingkungan di SMA Budi Mulia Bogor
tergolong bersih. Hal ini dapat dilihat
dari tidak adanya sampah yang
berserakan di lingkungan sekolah, baik
di lapangan, koridor maupun ruangruang kelas. Keadaan toilet yang terawat, serta adanya banyak tumbuhan di lingkungan sekolah seperti: Lidah Mertua, Pohon Cemara, Palem Kuning, Euphorbia sp., Paku Tanduk Rusa, Dieffenbachia sp., Pucuk Merah, Sirih Merah, dan lainnya yang ditaruh di setiap koridor, di dekat kolam, dan juga di beberapa ruangan. SMA Budi Mulia memiliki ruang terbuka khusus yang disebut dengan "pintu surga". Awalnya, ruang terbuka ini dipakai untuk menyimpan berbagai tanaman hias dan obat seperti: Kucai Tulip, Temulawak, Jahe, Kencur, dan tanaman lainnya yang dibawa oleh para siswa setiap tahunnya. Oleh karena kurangnya perawatan, tanaman-tanaman tersebut mati. Saat ini Pintu surga sedang dalam proses untuk dijadikan tempat hidroponik.

\section{Perilaku Hidup Bersih dan Sehat (PHBS) \\ PHBS merupakan sebuah upaya} dengan tujuan untuk memberikan pengalaman, dan pemahaman kepada masyarakat mengenai pola hidup sehat dan bersih yang berkaitan dengan kesehatan sehingga masyarakat dapat mencegah dan mengatasi permasalahan kesehatan di lingkungan sekitar masyarakat. Indikator PHBS dalam penelitian ini antara lain: (1) penggunaan air bersih; (2) mencuci tangan dengan baik dan benar; (3) mengkonsumsi makanan sehat dan bergizi; (4) melakukan aktivitas fisik setiap hari; (5) menuruti protokol kesehatan pemerintah; dan (6) istirahat yang baik dan cukup. 

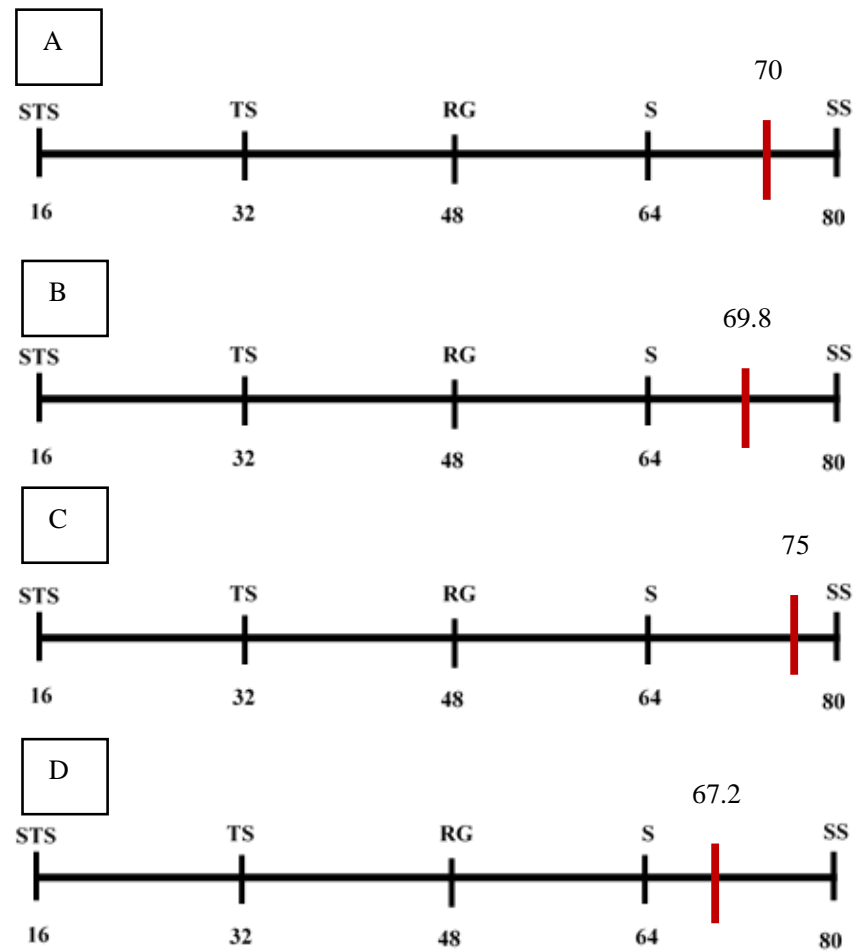

Gambar 3. Garis Kontinum PHBS (A) Skor Kepala Sekolah; (B) Skor Guru; (C) Skor Karyawan; (D) Skor Siswa (Sumber: Dokumen Penulis)

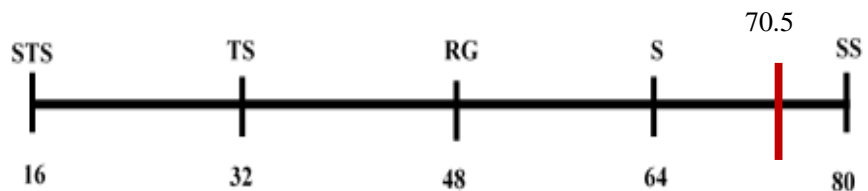

Gambar 4. Garis Kontinum Sikap Peduli Lingkungan warga SMA Budi Mulia Kota Bogor (Sumber: Dokumen Penulis)

Data PHBS per strata disajikan pada Gambar 1. Apabila dilihat per strata, maka kesimpulan tingkat persetujuan terhadap PHBS adalah sebagai berikut.

a. Kepala Sekolah $=(70: 80) \times 100 \%=$ $87.5 \%$ dari yang diharapkan $100 \%$

b. Guru $=(69.8: 80) \times 100 \%=87.25 \%$ dari yang diharapkan $100 \%$

c. Karyawan = $(75: 80)$ $x 100 \%=93.75 \%$ dari yang diharapkan $100 \%$

d. Siswa $=(67.2: 80) \times 100 \%=84 \%$ dari yang diharapkan $100 \%$

Rerata skor yang diperoleh dari 255 responden yang terdiri atas kepala sekolah, guru, karyawan, dan siswa adalah 77.38. Dengan demikian, sikap peduli lingkungan warga SMA Budi Mulia Kota Bogor $=(70.5: 80) \times 100 \%=$ $88.13 \%$ dari yang diharapkan $100 \%$. Data secara keseluruhan mengenai gambaran PHBS disajikan pada.

Berdasarkan observasi mengenai PHBS yang diterapkan di SMA dapat dilihat bahwa pegawai yang masuk kerja (offline) di SMA Budi Mulia sangat sadar dengan keadaan pandemi Covid-19, seprti penggunaan masker, mencuci tangan, dan physical distancing. Hal ini sesuai pernyataan bahwa Covid-19 dapat dikendalikdan dengan penggunaan masker, penerapan PHBS, serta penerapan physical distancing(Zhou, 2020). Pencegahan Covid-19 juga bisa dapat 
melalui pengkonsumsian makanan dengan gizi seimbang, menjaga jarak, mencuci tangan yang benar dapat mencegah penularan Covid19(Atmadja et al., 2020).

Sikap peduli lingkungan dapat menjadi salah satu awalan dalam mencegah dan mengurangi permasalahan lingkungan yang ada. Sikap peduli lingkungan harus ditanamankan dan dikembangkan melaui pendidikan karakter sedini mungkin. Hak dan tanggung jawab terhadap lingkungan harus diadopsi di sekolah dan diikuti dengan penerapan model pelarihan yang menargetkan pada sikap dan perilaku lingkungan siswa (Altin et al., 2014). Hal ini terlebih di masa pandemi Covid-19 ini, kebersihan lingkungan sangatlah penting. Penerapan Perilaku Hidup Bersih dan Sehat (PHBS) yang baik dapat mencegah penularan Covid-19 (Antari et al., 2020).

Guru menjadi teladan siswa dalam sikap peduli lingkungan dan PHBS. Tentunya dalam mendidik siswa sesuai dengan ajaran kasih. Tindakan mendidik oleh guru yang dilandasi dengan kasih, berdampak positif pada perilaku siswa baik di lingkungan sekolah, keluarga, dan masyarakat (Martinus \& Amadi, 2020).

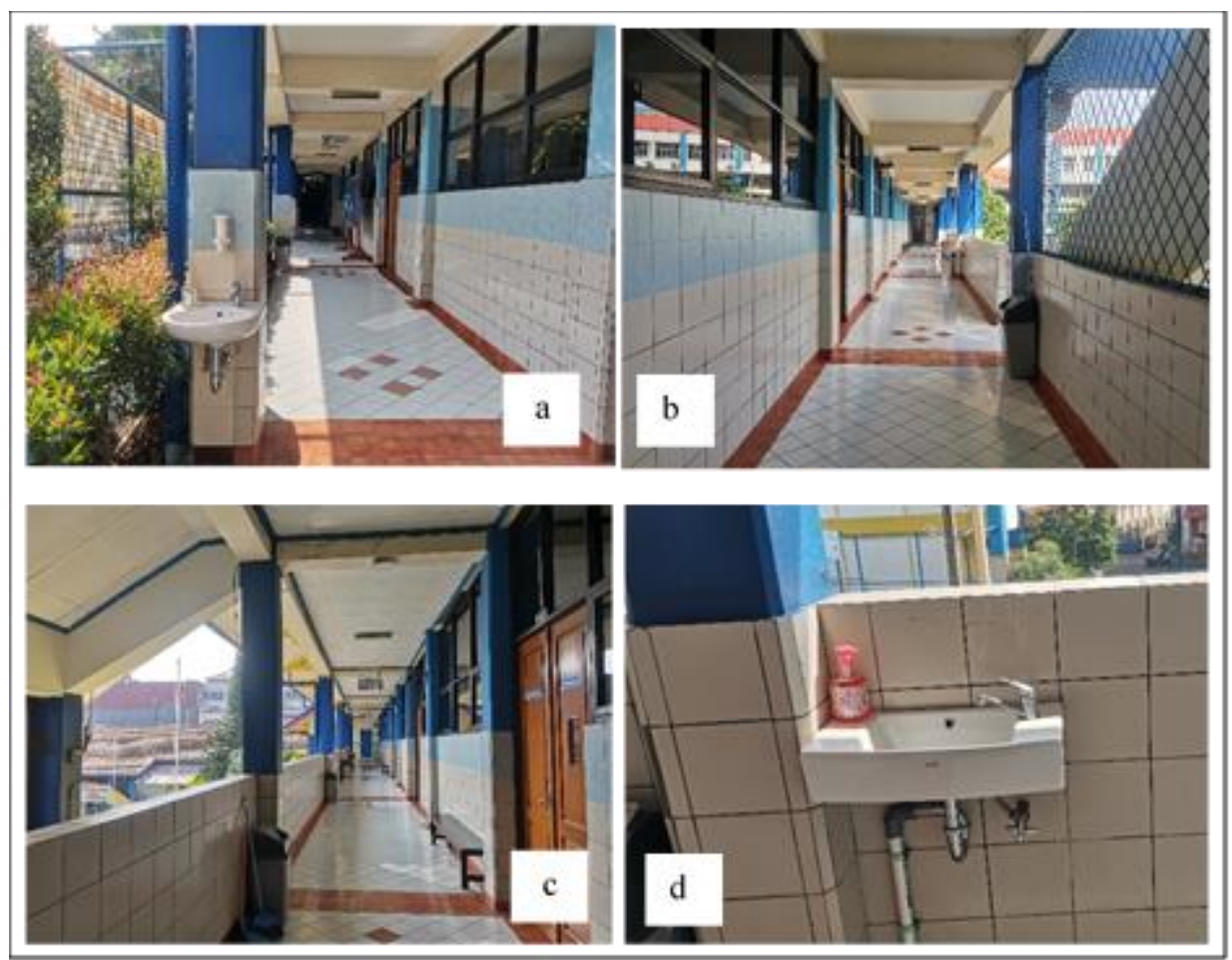

Gambar 5. Keadaan Koridor Sekolah; (a) Koridor lantai 1; (b) Koridor lantai 2; (c) Koridor lantai 3; dan (d) wastafel di setiap koridor (Sumber: Dokumen Penulis)

Dalam mengatasi Pandemi Covid-19, harus terjadi sinergi antara sikap peduli lingkungan dan PHBS di semua warga sekolah. Berdasarkan hasil observasi dan wawancara maka didapatkan temuan sebagai berikut.

1. Satpam sekolah selalu mengecek suhu orang-orang yang masuk kedalam lingkungan sekolah dan mengarahkan orang-orang untuk menggunakan handsinitizer yang telah disediakan

2. Setiap individu yang berada di SMA Budi Mulia diwajibkan memakai masker selama berada di lingkungan sekolah 
3. Setiap personalia yang penulis lihat selalu mencuci tangan setelah melakukan kegiatan.

4. Lingkungan sekolah masih terdapat berbagai macam tumbuhan.

5. Semasa pandemi Covid-19, SMA Budi Mulia telah mempersiapkan saran dan prasarana pendukung yang sesuai dengan peraturan kementiran pendidikan, seperti penambahan wastafel yang dilengkapi dengan sabun cuci tangandi koridor yang ditempatkan di hampir setiap pintu depan kelas.

6. Setiap koridor memiliki tempat sampah.

7. Adanya pemberian jarak pada penempatan meja guru di ruang guru.

8. Satu kelas hanya diisi oleh satu guru.

9. Di tempat-tempat yang dikunjungi oleh orang umum, seperti ruang

\section{Kesimpulan}

Warga SMA Budi Mulia Kota Bogor sudah memiliki sikap peduli lingkungan sebesar $86.06 \%$ dari indikator yang diharapkan, seperi: (1) Penggunaan energi; (2) pemanfaatan air; (3) pengelolaan sampah; (4) pengetahuan terhadap pencemaran; (5) penggunaan plastik; (6) penggunaan transportasi umum; dan (7) perawatan dan pemanfaatan lingkungan di sekitar. Perilaku Hidup Bersih dan Sehat warga SMA Budi Mulia Kota Bogor sebesar $88.13 \%$ kepala sekolah dan tata usaha ditempatkan handsinitizer.

Ajakan peduli lingkungan juga diserukan oleh Paus Fransiskus yang mengeluarkan sebuah ensiklik berjudul "Laudato si', on care for our common home." tentang ajakan merawat bumi sebagai rumah bersama sebaikbaiknya, juga demi generasi yang akan dating (Keuskupan Agung Jakarta, 2016). Keuskupan Agung Jakarta mengatakan perlu dilakukan pertobatan terhadap hutang dan dosa ekologis, seperti: pantikfoam (pantang plastik dan Styrofoam) dan gerakan memilah dan mengolah sampah (Keuskupan Agung Jakarta, 2016). SMA Budi Mulia merupakan sekolah katolik yang tentunya juga dapat bersinergi dalam mewujudkan sikap peduli lingkungan dan perilaku hidup sehat.

dari indikator yang diharapkan, seperti: (1) penggunaan air bersih; (2) mencuci tangan dengan baik dan benar; (3) mengkonsumsi makanan sehat dan bergizi; (4) melakukan aktivitas fisik setiap hari; (5) menuruti protokol kesehatan pemerintah; dan (6) istirahat yang baik dan cukup. SMA Katolik sebaiknya menjadi teladan dalam gerakan sikap peduli lingkungan dan PHBS karena didukung dan sesuai semangat Gereja Katolik dalam kaitannya dengan lingkungan.

\section{Daftar Pustaka}

Altin, A., Tecer, S., Tecer, L., Altin, S., \& Kahraman, B. F. (2014). Environmental Awareness Level of Secondary School Students: A Case Study in Balıkesir (Türkiye). Procedia - Social and Behavioral Sciences, 141, 1208-1214. https://doi.org/10.1016/j.sbspro.2014.05.207 
Antari, N. P. U., Dewi, N. P. K., Putri, K. A. K., Rahayu, L. R. P., Wulandari, N. P. N. K., Ningsih, N. P. A. W., Pertiwi, N. W. A., Cahyanti, N. P. S. D. C., Damayanti, M. E. A., Dewi, M. T. L., Candrayani, K. T., \& Jati, G. B. K. A. (2020). Perilaku Hidup Bersih Dan Sehat Mahasiswa Universitas Mahasaraswati Denpasar Selama Pandemi Covid-19. Jurnal IImiah Medicamento, 6(2), 94-99. https://doi.org/10.36733/medicamento.v6i2.1056

Atmadja, T. F. A., Yunianto, A. E., Yuliantini, E., Haya, M., Faridi, A., \& Suryana, S. (2020). Gambaran sikap dan gaya hidup sehat masyarakat Indonesia selama pandemi Covid-19. AcTion: Aceh Nutrition Journal, 5(2), 195. https://doi.org/10.30867/action.v5i2.355

Gromico, A. (2019). Indonesia Penghasil Sampah Plastik Nomor Dua di Dunia Tirto.ID. https://tirto.id/indonesia-penghasil-sampah-plastik-nomor-dua-di-duniadeyY

Gunawan, H., \& Guslinda, G. (2019). Analisis Sikap Peduli Lingkungan Siswa Sd Negeri 184 Pekanbaru. Primary: Jurnal Pendidikan Guru Sekolah Dasar, 8(2), 139. https://doi.org/10.33578/jpfkip.v8i2.7631

Handayani, A. (2013). Peningkatan Sikap Peduli Lingkungan Melalui Implementasi Pendekatan Sains Teknologi Masyarakat (STM) dalam Pembelajaran IPA Kelas IV.1 SD N Keputran "A."

Keuskupan Agung Jakarta. (2016). Gerakan Silih Ekologis. Jakarta: Keusukupan Agung Jakarta.

Lathif, N. (2019). Kewenangan Penyelenggaraan Program Pengurangan Kantong Plastik Di Wilayah Kota Bogor. Jurnal Gagasan Hukum, 1(1), 41-62.

Listyanto, D. (2019). Katekase Ekologi Sebagai Bentuk Keterlibatan Penggerak Lingkungan Hidup dala Upaya Menjaga dan Merawat Kelestarian Lingkungan Hidup di Paroki Santo Yusup Baturetno Wonogiri.

Martinus \& Amadi. (2020). Dampak Pendidikan Agama Katolik Terhadap Perilaku Siswa di Sekolah Negeri di Kota Pontianak. Vocat: Jurnal Pendidikan Katolik, 1 (1): 37-43.

Sari, E., \& Ria, R. (2018). Hubungan Sikap Peduli Lingkungan Hidup Serta Perilaku Hidup Bersih dan Sehat dengan Prestasi Belajar Mahasiswa. Bio-Lectura: Jurnal Pendidikan Biologi, 6(2), 160-171.

Subdirektorat Statistik Lingkungan Hidup. (2018). Laporan Indeks Perilaku Ketidakpedulian Lingkungan Hidup Indonesia 2018. BPS-RI.

Sugiyono. (2016). Metode Penelitia Pendidika Pendekatan Kuantitatif, Kualitatif, dan $R \& D$ (23rd ed.). ALFABETA.

Wetu, H. E. (2017). Pendidikan Karakter sebagai Bagian dari Revolusi Mental Menurut Pandangan Gereja Katolik.

Zhou, W. (2020). The Coronavirus Prevention Handbook. 
